\title{
Maternofetal Transmission of IgG-Bound Hepatitis B e Antigen
}

\author{
KOSHU ARAKAWA, FUMIO TSUDA, KAZUAKI TAKAHASHI, IKU ISE, SHIGEKO NAITO, \\ EMIKO KOSUGI, YUZO MIYAKAWA AND MAKOTO MAYUMI ${ }^{(26)}$
}

Hamanomachi Hospital, Hepatitis Division, Tokyo Metropolitan Institute of Medical Science, Immunology Division, Jichi Medical School, and the Third Department of Internal Medicine, University of Tokyo, Japan

\section{Summary}

Utilizing a highly sensitive radioimmunoassay, hepatitis $B$ e antigen (HBeAg) was detected in the cord serum of eight out of nine babies born to mothers who carried hepatitis B surface antigen together with $\mathrm{HBeAg}$. The titer of $\mathrm{HBeAg}$ in the cord serum was much lower than that in the corresponding maternal serum, and escaped the detection by the conventional micro-Ouchterlony immunodiffusion. HBeAg in maternal and cord sera was fractionated into free and IgG-bound moieties by salt precipitation, and their proportion was compared in four pairs. In every pair tested, both free and IgG-bound HBeAg were found in the maternal serum, but only IgG-bound $\mathrm{HBeAg}$ was detected in the corresponding cord serum. Based on these results, IgG-bound HBeAg can be transmitted through the placenta, but free $\mathrm{HBeAg}$ may barely pass the placenta despite its much smaller size.

\section{Speculation}

Among macromolecules present in the maternal circulation, only IgG is known to be transmitted into fetal circulation. The presence of IgG-bound $\mathrm{HBeAg}$, but not of free $\mathrm{HBeAg}$, in the cord serum of babies born to HBeAg-positive mothers suggests that IgG would be responsible for the materr.ofetal transmission of HBeAg.

Hepatitis B virus (HBV) transmits vertically, from infected mothers to their children. We have previously reported that children born to mothers who carried hepatitis B surface antigen (HBsAg) and were seropositive for hepatitis B e antigen ( $\mathrm{HBeAg}$ ) developed persistent $\mathrm{HBV}$ infection within 6 months after delivery, whereas children born to carrier mothers seropositive for antibody to $\mathrm{HBeAg}$ (anti-HBe) escaped persistent infection (13). Despite the apparent mother to child transmission of $\mathrm{HBV}$, the exact route by which children acquire $\mathrm{HBV}$ infection remains uncertain. It has been repeatedly reported that $\mathrm{HBsAg}$ was not or rarely detectable in the cord serum of babies who were born to carrier mothers and later developed persistent HBs antigenemia $(12,14)$. $\mathrm{We}$, as well as others, $(3,24)$ have not been able to find $\mathrm{HBeAg}$ even in the cord serum of babies who were born to $\mathrm{HBeAg}$ positive carrier mothers and acquired persistent $\mathrm{HBV}$ infection.

Previous failure to identify $\mathrm{HBeAg}$ in the cord serum may relate to the insensitivity of the methods applied. By means of a sensitive radioimmunoassay, we have detected $\mathrm{HBeAg}$ in the cord serum of babies born to carrier mothers seropositive for $\mathrm{HBeAg}$. Furthermore, $\mathrm{HBeAg}$ bound to $\mathrm{IgG}$, but not free $\mathrm{HBeAg}$, was found to be capable of passing the placenta.

\section{MATERIALS AND METHODS}

\section{SUBJECTS}

Eight pregnant women were identified who were asymptomatic carriers of $\mathrm{HBsAg}$ and seropositive for $\mathrm{HBeAg}$. Their prepartum serum and cord serum of their babies were tested in pairs for HBV-associated antigens and antibodies. One of the mothers (Case 6) labored twice, while she kept $\mathrm{HBsAg}$ and $\mathrm{HBeAg}$ at the age of 25 and 27 , and was tested on 2 occasions. In total therefore, nine pairs of maternal and cord sera were available for the test. Criteria for asymptomatic carriers of HBV consisted of: (1) the presence of $\mathrm{HBsAg}$ in the serum by tests performed at least 6 months apart; and (2) no signs and symptoms of hepatitis with serum transaminase levels within normal limits. All of the babies were born after full-term of pregnancy, and free of any anomalies on visual inspection at birth. Out of nine babies in the series, four (Cases 2, 6-1, 7 and 8) developed the persistent carrier state of HBV within the first 6 months of their lives.

\section{SEROLOGICAL TESTS}

HBsAg was determined by reversed passive hemagglutination method (23). Antibody to hepatitis B core antigen (anti-HBc) was determined by immune adherence hemagglutination method (22). $\mathrm{HBeAg}$ was determined by immunodiffusion method. The gel for micro-Ouchterlony was made of $0.9 \%$ agarose dissolved in Tris$\mathrm{HCl}$ buffer $(0.01 \mathrm{M}, \mathrm{pH} 7.6)$ containing $0.1 \mathrm{M} \mathrm{NaCl}, 0.1 \% \mathrm{NaN}_{3}$, $0.02 \mathrm{M}$ ethylene diaminetetraacetic acid, 2\% dextran T500 (Pharmacia Fine Chemicals, Uppsala) and $2 \%$ polyethylene glycol-6000 (Iwai Kagaku, Tokyo). Wells of $3 \mathrm{~mm}$ in diameter were cut $2 \mathrm{~mm}$ apart in a hexagonal arrangement. The undiluted sample was tested against standard anti- $\mathrm{HBe}$ and $\mathrm{HBeAg}$ reagents and the fusion of precipitin lines was observed under an inverted microscope.

HBeAg was determined also by a modification of the microtiter solid phase radioimmunoassay described previously (9). Human anti-HBe to coat a polyvinyl microtiter plate (Cooke Engineering Co., Alexandria, VA.) and for radiolabeling was purified by affinity column chromatography and gel filtration in Sephadex $\mathrm{G}-200$ (17). Into wells of the microplate coated with anti-HBe, 50 $\mu \mathrm{l}$ of the test serum, undiluted or diluted 2- to 100 -fold, were transferred. After an incubation at $24^{\circ} \mathrm{C}$ for $2 \mathrm{~h}$ and then at $4^{\circ} \mathrm{C}$ for overnight, the plate was washed 5 times with isotonic saline. One hundred $\mu \mathrm{l}$ of a solution containing anti-HBe labeled with ${ }^{125} \mathrm{I}(100 \mathrm{ng}, 7 \mu \mathrm{Ci} / \mu \mathrm{g})$ were delivered into each well and the plate was further incubated at $24^{\circ} \mathrm{C}$ for $2 \mathrm{~h}$ and at $4^{\circ} \mathrm{C}$ overnight. The plate was washed 5 times with isotonic saline, and the bound radioactivity was counted. Twenty-five serum samples from normal individuals without $\mathrm{HBsAg}$ or anti-HBs were tested for $\mathrm{HBeAg}$ by the radioimmunoassay, and their average binding was determined. The result was expressed by CPM of the test sample divided by the average CPM of normal sera. The sample was considered to be positive for $\mathrm{HBeAg}$ when the ratio exceeded a cut-off value of 2.1. Figure 1 depicts the binding curve of a HBeAg-positive serum serially diluted up to 10,000 -fold. The serum showed a steep slope of binding and the ratio exceeded the cut-off value of 2.1 up to a 3,000-fold dilution. The other $\mathrm{HBeAg}$ positive sera showed similarly steep binding curves. 


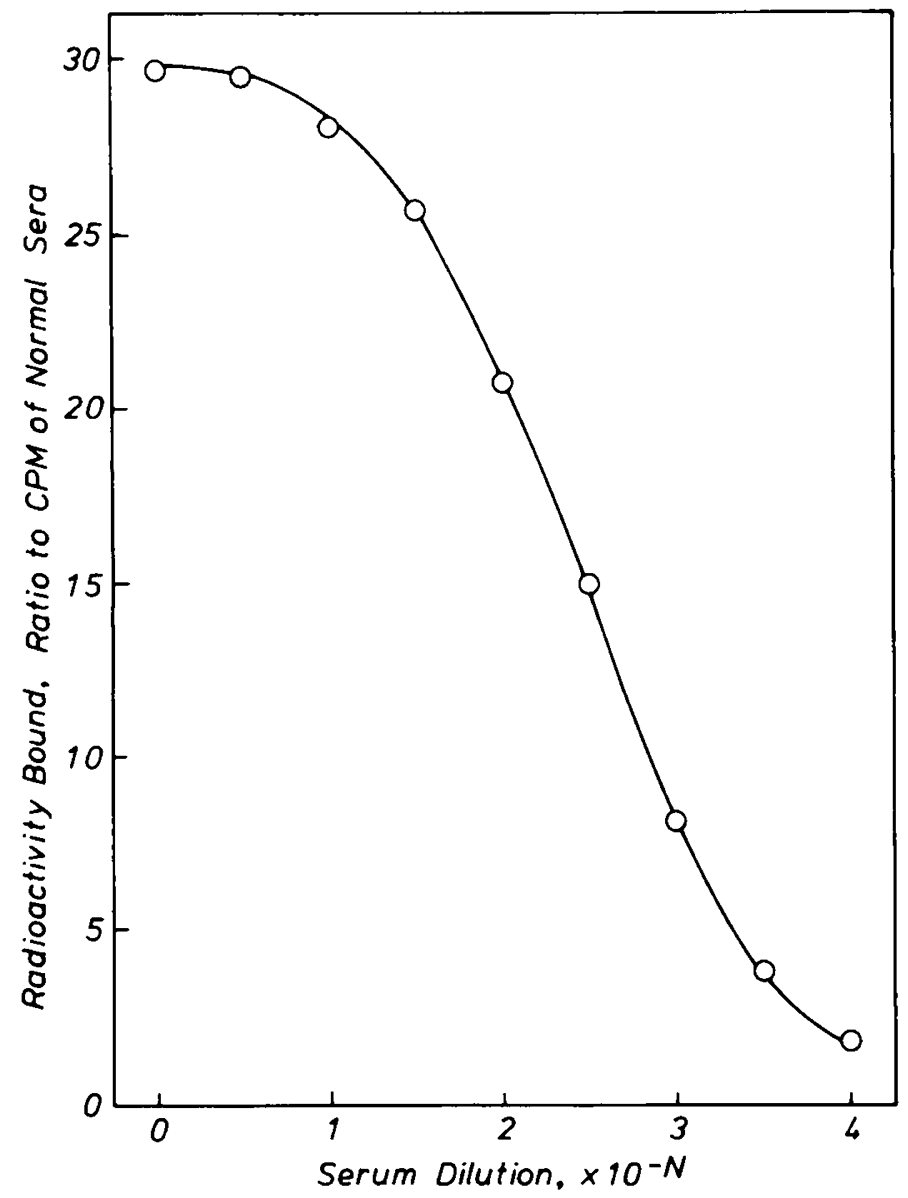

Fig. 1. Microtiter solid phase radioimmunoassay of hepatitis B e antigen. The binding curve of a serum sample containing $\mathrm{HBeAg}$ is shown. The binding was expressed by the ratio of CPM of the sample to the average $\mathrm{CPM}$ of normal sera. $\mathrm{HBeAg}$ was regarded to be positive when the ratio exceeded the cut-off value of 2.1 .

\section{SEPARATION OF IgG-BOUND HBeAg FROM FREE HBeAg}

HBeAg in the serum has been shown to occur in two physicochemically and antigenically different forms, i.e., free "small" $\mathrm{HBeAg}$ and IgG-bound "large" $\mathrm{HBeAg}$ (18). Free and IgG-bound moieties of $\mathrm{HBeAg}$ in the test serum were separated from each other by a salt precipitation in $\left(\mathrm{NH}_{4}\right)_{2} \mathrm{SO}_{4}$. To determine the concentration of $\left(\mathrm{NH}_{4}\right)_{2} \mathrm{SO}_{4}$ for an efficient separation, an aliquot of the serum containing both free and $\mathrm{IgG}$-bound $\mathrm{HBeAg}$ was mixed with a varying volume of saturated $\left(\mathrm{NH}_{4}\right)_{2} \mathrm{SO}_{4}$ solution at $24^{\circ} \mathrm{C}$. The formed precipitate was separated by centrifugation at $6,600 \times g$ for $15 \mathrm{~min}$. Precipitate was then dissolved in a portion of water. Both precipitate and supernatant were dialysed extensively against Tris- $\mathrm{HCl}$ saline, concentrated, and subjected to disc electrophoresis in polyacrylamide gel. After electrophoresis, the gel $(5 \times 100 \mathrm{~mm})$ was cut into $3.2 \mathrm{~mm}$ slices. Each slice was eluted with an aliquot of buffer, and the $\mathrm{HBeAg}$ activity was detected by the inhibition on hemagglutination of sheep erythrocytes coated with purified $\mathrm{HBeAg}$ by a limited amount of anti-HBe (17). Patterns of precipitate and supernatant of the serum fractionated at $33.3 \%$ saturation with $\left(\mathrm{NH}_{4}\right)_{2} \mathrm{SO}_{4}(A), 34.9 \%(B), 36.5 \%(C)$ and $38.4 \%(D)$, are illustrated in Figure 2 . At low saturation with $\left(\mathrm{NH}_{4}\right)_{2} \mathrm{SO}_{4}$, some IgG-bound $\mathrm{HBeAg}$ activity remained in the supernatant $(A$ and $B$ ), whereas at higher saturation, free $\mathrm{HBeAg}$ contaminated in the precipitate $(D)$. Based on these observations, $36.5 \%$ saturation $(C)$ was adopted for an efficient separation of free $\mathrm{HBeAg}$ from the IgG-bound form.

\section{RESULTS}

Table 1 summarizes the results of tests for $\mathrm{HBV}$-associated antigens and antibodies in nine pairs of maternal and cord sera.
All the maternal sera were positive for $\mathrm{HBsAg}$ with titers ranging from $2^{9}$ to $2^{12}$. None of cord sera of their babies, however, revealed any $\mathrm{HBsAg}$ detectable by the hemagglutination method. The titers of anti-HBc in maternal sera were high $\left(2^{10}-2^{16}\right)$, in accordance with their persistent carriage of $\mathrm{HBV}(6)$. Cord sera were also positive for anti-HBc with titers essentially unchanged from those of corresponding mothers.

All the maternal sera were positive for $\mathrm{HBeAg}$, but none of cord sera were positive as tested by micro-Ouchterlony immunodiffusion test. HBeAg in serum samples from mother and cord was tested at appropriate dilution by the radioimmunoassay. Except for Case 8, the same dilution was maintained within each pair to facilitate comparison; $\mathrm{HBeAg}$ in the cord serum of Case 8 was too low to be tested at the same dilution as the corresponding maternal serum. Except for Case 3, all of cord sera were positive for $\mathrm{HBeAg}$ by the radioimmunoassay, albeit the activity was much lower than that in the corresponding maternal serum. The maternal serum of Case 3 showed a low activity of $\mathrm{HBeAg}$, therefore it had to be tested undiluted. The cord serum of Case 3, even when tested undiluted, was negative for $\mathrm{HBeAg}$. A wide variation in the difference between maternal and cord sera indicated that not a constant fraction of $\mathrm{HBeAg}$, but a particular population of $\mathrm{HBeAg}$ in the maternal serum would be able to pass the placenta.

Because there are two forms of $\mathrm{HBeAg}$ in the serum, free and IgG-bound $\mathrm{HBeAg}$ (18), we studied which form of $\mathrm{HBeAg}$ could pass the placenta more easily than the other by comparing the proportion of free and IgG-bound $\mathrm{HBeAg}$ activities between paired maternal and cord sera. Table 2 gives the results of such determination in four pairs for which enough amount of serum was available. $\mathrm{HBeAg}$ in the maternal serum was tested at 10 -fold dilution, but owing to the low concentration of $\mathrm{HBeAg}$, the cord serum was tested undiluted, with the provision that the dilution would not affect the ratio of free $\mathrm{HBeAg}$ to IgG-bound form. Both

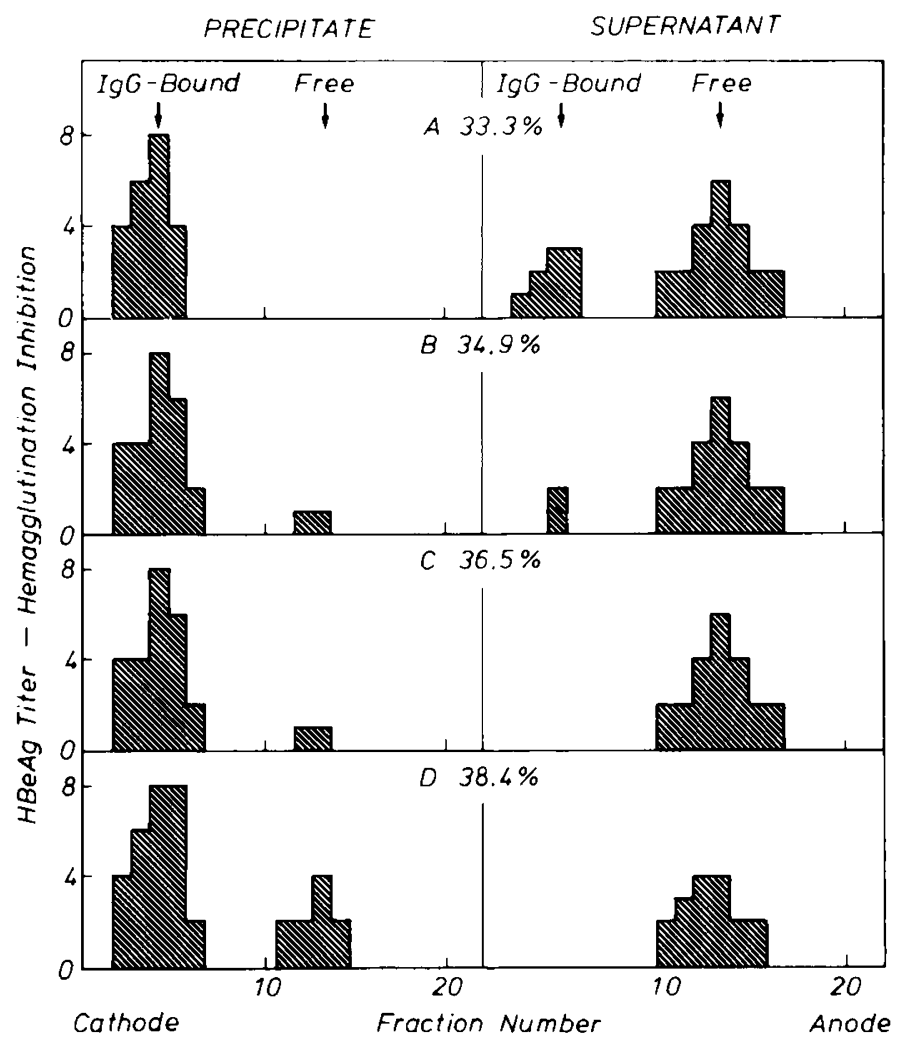

Fig. 2. Separation of free and IgG-bound $\mathrm{HBeAg}$ in the serum by salt precipitation. The serum containing $\mathrm{HBeAg}$ was precipitated at $33.3 \%$ saturation with $\left(\mathrm{NH}_{4}\right)_{2} \mathrm{SO}_{4}(A), 34.9 \%(B), 36.5 \%(C)$, and $38.4 \%(D)$. Thereafter, both precipitate and supernatant were tested for free and IgGbound $\mathrm{HBeAg}$ by disc electrophoresis in polyacrylamide gel. Shaded areas represent $\mathrm{HBeAg}$ determined by the inhibition of passive hemagglutination, and arrows indicate the positions of free and IgG-bound $\mathrm{HBeAg}$. 
Table 1. Hepatitis B virus-associated antigens and antibodies in maternal and cord sera

\begin{tabular}{|c|c|c|c|c|c|c|c|c|c|c|c|}
\hline \multirow[b]{3}{*}{ Case No. } & \multirow[b]{3}{*}{ Age } & \multicolumn{5}{|c|}{ Maternal serum } & \multicolumn{5}{|c|}{ Cord serum } \\
\hline & & \multirow{2}{*}{$\begin{array}{c}\mathrm{HBsAg}^{1} \\
2^{\mathrm{N}}\end{array}$} & \multirow{2}{*}{$\begin{array}{l}\text { Anti- } \\
\mathrm{HBc}^{2} \\
2^{\mathrm{N}}\end{array}$} & \multicolumn{3}{|c|}{ HBeAg } & \multirow{2}{*}{$\begin{array}{c}\mathrm{HBsAg}^{\prime} \\
2^{N}\end{array}$} & \multirow{2}{*}{$\begin{array}{c}\text { Anti- } \\
\mathrm{HBc}^{2} \\
2^{\mathrm{N}}\end{array}$} & \multicolumn{3}{|c|}{ HBeAg } \\
\hline & & & & $\mathrm{ID}^{3}$ & RIA $^{4}$ & $\begin{array}{c}\text { Tested } \\
\text { at }\end{array}$ & & & $\mathrm{ID}^{3}$ & $\mathrm{RIA}^{4}$ & $\begin{array}{c}\text { Tested } \\
\text { at }\end{array}$ \\
\hline 1 & 25 & 10 & 13 & + & 10.7 & $1: 100$ & & 14 & & 5.9 & $1: 100$ \\
\hline 2 & 27 & 11 & 10 & + & 12.4 & $1: 100$ & & 10 & & 2.8 & $1: 100$ \\
\hline 3 & 32 & 9 & 10 & + & 23.6 & undiluted & & 9 & & 1.7 & undiluted \\
\hline 4 & 30 & 10 & 16 & + & 25.4 & $1: 2$ & & 16 & & 7.8 & $1: 2$ \\
\hline 5 & 28 & 10 & 12 & + & 26.8 & $1: 2$ & & 13 & & 3.9 & $1: 2$ \\
\hline $6 a$ & 25 & 12 & 15 & + & 15.4 & $1: 100$ & & 16 & & 6.9 & $1: 100$ \\
\hline $6 b$ & 27 & 9 & 16 & + & 13.6 & $1: 100$ & & 16 & & 2.5 & $1: 100$ \\
\hline 7 & 24 & 11 & 10 & + & 10.0 & $1: 100$ & & 10 & & 2.4 & $1: 100$ \\
\hline 8 & 30 & 11 & 15 & + & 12.6 & $1: 100$ & & 15 & & 11.2 & $1: 10$ \\
\hline
\end{tabular}

${ }^{1}$ Hepatitis B surface antigen was determined by reversed passive hemagglutination method (23).

${ }^{2}$ Antibody to hepatitis B core antigen was determined by immune adherence hemagglutination method (22).

${ }^{3}$ Hepatitis B e antigen was determined by micro-Ouchterlony immunodiffusion method.

${ }^{4}$ Hepatitis B e antigen was also determined in the serum diluted as indicated by microtiter solid phase radioimmunoassay (see "Materials and Methods").

Table 2. IgG-bound and free hepatitis $B$ e antigen in maternal and cord sera

\begin{tabular}{cccccccc} 
& & \multicolumn{2}{c}{$\mathrm{HBeAg}$ in maternal serum } & \multicolumn{3}{c}{$\mathrm{HBeAg}$ in cord serum } \\
\cline { 2 - 6 } \cline { 5 - 7 } Case No. & IgG-bound & Free & $\begin{array}{c}\text { Tested } \\
\text { at }\end{array}$ & IgG-bound & Free & $\begin{array}{c}\text { Tested } \\
\text { at }\end{array}$ \\
\hline 1 & 13.0 & 2.7 & $1: 10$ & 21.0 & $<1$ & $1: 1$ \\
2 & 18.0 & 7.4 & $1: 10$ & 14.0 & $<1$ & $1: 1$ \\
7 & 12.2 & 7.4 & $1: 10$ & 14.6 & $<1$ & $1: 1$ \\
8 & 16.0 & 4.1 & $1: 10$ & 12.1 & $<1$ & $1: 1$ \\
\hline
\end{tabular}

${ }^{1}$ Serum samples were precipitated at $36.5 \%$ saturation with $\left(\mathrm{NH}_{4}\right)_{2} \mathrm{SO}_{4}$. Both precipitate and supernatant were reconstituted to the original volume and tested for $\mathrm{HBeAg}$ by microtiter solid phase radioimmunoassay. Maternal serum was tested at 1:10 dilution, but cord serum was tested undiluted due to low concentration of $\mathrm{HBeAg}$ contained.

IgG-bound and free forms of $\mathrm{HBeAg}$ were found in the maternal serum. In remarkable contrast, free $\mathrm{HBeAg}$ was not detectable in the cord serum, despite the detection of IgG-bound $\mathrm{HBeAg}$ with a titer comparable to that in the corresponding maternal serum. The possibility still remains that free $\mathrm{HBeAg}$ might have been present in the cord serum at a concentration too low to be detected by the method employed. It can be reasonably assumed, however, that the ratio of free $\mathrm{HBeAg}$ to IgG-bound form was much lower in the cord serum than that in the corresponding maternal serum. On the basis of these observations, IgG-bound $\mathrm{HBeAg}$ in the maternal circulation can be transmitted through the placenta into fetal circulation, but free $\mathrm{HBeAg}$ may barely pass the placenta in spite of its much smaller size.

\section{DISCUSSION}

The presence of $\mathrm{HBeAg}$ in the serum of mothers who carry $\mathrm{HBV}$ was closely associated with the vertical transmission of $\mathrm{HBV}$ (13). The presence of $\mathrm{HBeAg}$ in $\mathrm{HBsAg}$-positive sera also signaled the infectivity in horizontal transmission of HBV (1). The experimental transmission of $\mathrm{HBV}$ infection to chimpanzees, sera from asymptomatic carriers containing $\mathrm{HBeAg}$ were at least $10^{6}$ times more infectious than those containing anti-HBe (15). These findings are reinforced by the correlation of $\mathrm{HBeAg}$ with immunologic and biochemical tags of Dane particles [the presently accepted $\mathrm{HBV}$ (2)], such as HBcAg and $\mathrm{HBsAg}$-associated DNA polymerase $(7,11,16)$. Recently, direct evidence for the association of Dane particles and HBeAg was provided by demonstrating polypeptides with $\mathrm{HBeAg}$ activity, P19 and P45, in their cores (19).
$\mathrm{HBeAg}$ has been shown to occur in the serum both free and in association with IgG molecules (18). There have been accumulating lines of evidence to suggest that $\mathrm{IgG}$ molecules bound to $\mathrm{HBeAg}$ would be antibodies directed to $\mathrm{HBeAg}$. In a chimpanzee experimentally infected with $\mathrm{HBV}$, free $\mathrm{HBeAg}$ appeared in the circulation first, gradually shifted to the IgG-bound form. Toward the end of infection, free $\mathrm{HBeAg}$ disappeared and the IgG-bound form represented all of the $\mathrm{HBeAg}$ activity. Finally, even IgGbound $\mathrm{HBeAg}$ disappeared to be taken over by anti-HBe (20). Another line of evidence in support of the immune complex nature of IgG-bound $\mathrm{HBeAg}$ would be its phlogistic activity to induce membranous glomerulonephritis in children who carry HBV (21).

Previous attempts to detect $\mathrm{HBeAg}$ in cord sera of babies born to carrier mothers who were seropositive for $\mathrm{HBeAg}$ have been unsuccessful $(3,24)$. By means of a sensitive radioimmunoassay, we could detect $\mathrm{HBeAg}$ activity in the cord serum of babies born to carrier mothers with circulating $\mathrm{HBeAg}$. Furthermore, IgGbound $\mathrm{HBeAg}$ was found to be capable of passing the placenta, while free $\mathrm{HBeAg}$ was not in spite of its much smaller size than the IgG-bound form.

The transmission of IgG-bound $\mathrm{HBeAg}$, but not of free $\mathrm{HBeAg}$, from mother to fetus may have to do with the selective transport of IgG molecules through the placenta. Gitlin et al. (4) reported that among macromolecules in the serum of mothers they studied, only IgG could pass the placenta into the cord serum with a concentration increasing to reach that in the maternal serum toward birth. The other molecules such as albumin, transferrin and IgM did not pass the placenta appreciably. They further extended their finding and demonstrated the binding of $\mathrm{IgG}$, but not of the other plasma proteins, with membrane fractions obtained from the placenta in vitro, and proposed the presence of a receptor for IgG on the placenta (5). There is a possibility that IgG-bound $\mathrm{HBeAg}$ would adhere to the surface of placenta by means of the receptor for IgG to be transmitted into the fetal circulation. McNabb et al. (8) showed that subclasses of IgG were different in their affinity to the placenta. In their study, $\operatorname{IgG}_{1}$ and $\mathrm{IgG}_{3}$ were equally affinitive to the placenta, but $\mathrm{IgG}_{4}$ was much less reactive. Neurath et al. (10) reported that the subclass of IgG in molecules with $\mathrm{HBeAg}$ activity was $\mathrm{IgG}_{4}$. Weak affinity of $\mathrm{IgG}_{4}$ for the placenta, a large size of IgG-bound $\mathrm{HBeAg}$, and inability for free $\mathrm{HBeAg}$ to pass the placenta would be among the factors responsible for the observed difference of $\mathrm{HBeAg}$ activity between maternal and cord sera.

The majority of the cases of vertical HBV transmission is thought to occur at the perinatal period; such transmission may be prevented by hepatitis B immune globulin given to babies after birth. There are occasional cases, however, in whom the transplacental passage of $\mathrm{HBV}$ has to be postulated. In two out of seven 
children born to carrier mothers who eventually acquired persistent $\mathrm{HBV}$ infection, $\mathrm{HBs} \mathrm{Ag}$ appeared in their circulation as early as on the 5th and 13th day, respectively, after birth (12). The possibility of Dane particles being capable of passing the placenta when bound to IgG, just as we have observed for $\mathrm{HBeAg}$, would deserve further considerations as a mechanism of the intrauterine infection of the fetus. Such IgG molecules could either be antiHBs or heretofore unidentified antibodies directed to Dane particles. Dane particles bearing IgG, if present, might be trapped onto the placenta by means of the receptor for IgG, taken up by pinocytosis, and transmitted into fetal circulation to initiate $\mathrm{HBV}$ infection in utero.

\section{REFERENCES AND NOTES}

1. Alter, H. J., Seeff, L. B., Kaplan, P. M., McAuliffe, V. J., Wright, E. C., Gerin, J. L., Purcell, R. H., Holland, P. V., and Zimmerman, H. J.: Type B hepatitis: the infectivity of blood positive for $e$ antigen and DNA polymerase after accidental needlestick exposure. N. Engl. J. Med., 295: 909 (1976).

2. Dane, D. S., Cameron, C. H., and Briggs, M.: Virus-like particles in serum of patients with Australia-antigen-associated hepatitis. Lancet, I: 695 (1970).

3. Gerety, R. J., and Schweitzer, I. L.: Viral hepatitis type B during pregnancy, the neonatal period, and infancy. J. Pediatr., 90: 368 (1977).

4. Gitlin, D., Kumate, J., Urrusti, J., and Morales, C.: The selectivity of the human placenta in the transfer of plasma proteins from mother to fetus. J. Clin. Invest., 10: 1938 (1964).

5. Gitlin, J. D., and Gitlin, D.: Cell receptors and the selective transfer of plasma proteins from mother to young across tissue barriers. Pediatr. Res., 7: 290 (1973).

6. Hoofnagle, J. H., Gerety, R. J., and Barker, L. F.: Antibody to hepatitis-B-virus in man. Lancet, 2: 869 (1973).

7. Imai, M., Tachibana, F. C., Moritsugu, Y., Miyakawa, Y., and Mayumi, M.: Hepatitis B antigen-associated deoxyribonucleic acid polymerase activity and e antigen/anti-e system. Infect. Immun., 14: 631 (1976).

8. McNabb, T., Koh, T. Y., Dorrington, K. J., and Painter, R. H.: Structure and function of immunoglobulin domains. V. Binding of immunoglobulin $G$ and fragments to placental membrane preparations. J. Immunol., 117: 882 (1976).

9. Miyakawa, Y., Tsuda, F., Akahane, Y., and Mayumi, M.: Application of microtitre solid-phase radioimmunoassay to the determination of hepatitis $B$ e antigen. Vox Sang., 36: 307 (1979).

10. Neurath, A. R., and Strick, N.: Host specificity of a serum marker for hepatitis $B$ : evidence that "e antigen" has the properties of an immunoglobulin. Proc. Natl. Acad. Sci. USA, 74: 1702 (1977).

11. Nordenfeld, E., and Kjellen, L.: Dane particles, DNA polymerase, and e-antigen in two different categories of hepatitis B antigen carriers. Intervirology, 5: 225 (1975)

12. Okada, K., Yamada, T., Miyakawa, Y., and Mayumi, M.: Hepatitis B surfsce antigen in the serum of infants after delivery from asymptomatic carrier mothers. J. Pediatr., 87: 360 (1975).

13. Okada, K., Kamiyama, I., Inomata, M., Imai, M., Miyakawa, Y., and Mayumi. $\mathbf{M}$.: $\mathrm{e}$ antigen and anti-e in the serum of asymptomatic carrier mothers as indicators of positive and negative transmission of hepatitis B virus to their children. New Engl. J. Med., 294: 746 (1976).

14. Schweizer, I. L., Mosley, J. W., Ashcavai, M., Edwards, V. M., and Obervy, L. B.: Factors influencing neonatal infection by hepatitis B virus. Gastroenterology, 65: 277 (1973).

15. Shikata, T., Karasawa, T., Abe, K., Uzawa, T., Suzuki, H., Oda, T., Imai, M. Mayumi, M., and Moritsugu, T.: Hepatitis-B e antigen and infectivity of hepatitis-B virus. J. Infect. Dis., 136: 571 (1977).

16. Takahashi, K., Imai, M., Tsuda, T., Takahashi, T., Miyakawa, Y., and Mayumi, M.: Association of Dane particles with e antigen in the serum of asymptomatic carriers of hepatitis B surface antigen. J. Immunol., 117: 102 (1976).

17. Takahashi, K., Fukuda, M., Baba, K., Imai, M., Miyakawa, Y., and Mayumi, M.: Determination of $e$ antigen and antibody to $e$ by means of passive hemagglutination method. J. Immunol., 119: 1556 (1977).

18. Takahashi, K., Imai, M., Miyakawa, Y., Iwakiri, S., and Mayumi, M.: Duality of hepatitis $\mathrm{B}$ e antigen in serum of persons infected with hepatitis $\mathrm{B}$ virus: evidence for the non-identity of e antigen with immunoglobulins. Proc. Natl. Acad. Sci. USA, 75: 1952 (1978).

19. Takahashi, K., Akahane, Y., Gotanda, T., Mishiro, S., Imai, M., Miyakawa, Y., and Mayumi, M.: Demonstration of hepatitis B e antigen in the core of Dane particles. J. Immunol., 122: 275 (1979).

20. Takahashi, K., Miyakawa, Y., Gotanda, T., Mishiro, S., Imai. M., and Mayumi M.: Shift from free "small" hepatitis B e antigen to IgG-bound "large" form in the circulation of humans and a chimpanzee acutely infected with hepatitis B virus. Gastroenterology, 77: 1193 (1979).

21. Takekoshi, Y., Tanaka, M., Miyakawa, Y., Yoshizawa, H., Takahashi, K., and Mayumi, M.: Free "small" and IgG-associated "large" hepatitis B e antigen in the serum and glomerular capillary walls of two patients with membranous glomerulonephritis. N. Engl. J. Med., 300: 814 (1979).

22. Tsuda, F., Takahashi, K., Takahashi, T., Miyakawa, Y., and Mayumi, M. Determination of antibody to hepatitis B core antigen by means of immune adherence hemagglutination. J. Immunol., 115: 834 (1975)

23. Vyas, G. N., and Shulman. N. R.: Hemagglutination assay for antigen and antibody associated with viral hepatitis. Science, 170: 332 (1970).

24. Yanagida, M., Horiguchi, S., Fuji, T., Okada, K., Nakao, C., Ishikawa, S., Miyakawa, Y., and Mayumi, M.: Failure of maternal transmission for small as well as large molecular hepatitis B e antigen. J. Pediatr., 95: 76 (1979).

25. Abbreviations used in this paper: hepatitis B virus, HBV; hepatitis B surface antigen, $\mathrm{HBsAg}$; antibody to $\mathrm{HBsAg}$, anti-HBs; hepatitis $\mathrm{B}$ core antigen, $\mathrm{HBcAg}$; antibody to $\mathrm{HBcAg}$, anti-HBc; hepatitis $\mathrm{B}$ e antigen, $\mathrm{HBeAg}$; antibody to $\mathrm{HBeAg}$. anti-HBe.

26. Requests for reprints should be addressed to: Dr. Makoto Mayumi, Hepatitis Division, The Tokyo Metropolitan Institute of Medical Science, 3-18 Honkomagome, Bunkyo-ku, Tokyo 113, Japan.

27. This research was supported in part by grants from the Japanese Ministry of Public Health and Welfare and the Tokyo Metropolitan Government.

28. Received for publication February 3, 1981 .

29. Accepted for publication July 26,1981 . 